\title{
STUDI IMPLEMENTASI KEBIJAKAN KAWASAN TANPA ROKOK PADA FASILITAS PELAYANAN KESEHATAN DI KABUPATEN BUNGO
}

\author{
FAJAR IFAN DOLLY ${ }^{1}$, \\ MAULIDA PUTRI RAHMAWATI' ${ }^{2}$ IKHSAN ALFARISI ${ }^{3}$ \\ ${ }^{1}$ Program Studi Ilmu Administrasi Negara, Sekolah Tinggi Ilmu Administrasi Setih Setio \\ Muara Bungo, Jambi. Email: fajarifandolly53@gmail.com \\ ${ }^{2}$ Program Studi Ilmu Pemerintahan, Universitas Selamat Sri, Kendal, Jawa Tengah. Email: \\ maulidaputri2791@gmail.com \\ ${ }^{3}$ Program Studi Ilmu Administrasi Negara, Sekolah Tinggi Ilmu Administrasi Setih Setio \\ Muara Bungo, Jambi. Email: ikhsan.alfarisi@gmail.com
}

\begin{abstract}
Various efforts to reduce the rate of active smoking in Bungo Regency and prohibit smoking activities in various places and certain public facilities are issuing local regulations on KTR. This study aims to determine and analyze the implementation of the KTR perda in health facilities, namely the puskesmas in Bungo Regency. This study uses a qualitative method approach with descriptive data. To see the success of the implementation of the KTR policy at puskesmas in Bungo District, the George Edwards III theory approach was used. For data analysis, an interactive model from Miles and Huberman was used. Data wetness used source triangulation approach. The results showed that the communication pattern of implementing the KTR perda at the health centers in Bungo Regency was carried out by socialization through a meeting chaired by the health department together with all the heads of the puskesmas. Then the message is forwarded to the entire community by the health center via verbabl and non-verbal communication. Because policy implementers do not get information directly, the implementation of the KTR perda is ideal as contained in the Ministry of Health's guidebook and the objectives of the KTR perda. The human resources for implementing the policy consist of leaders and employees appointed by the puskesmas. The budget for funds is still small in making KTR supporting facilities such as banners, stickers and there is no incentive for policy implementing employees. Full disposition from the health center and the community by providing verbal sanctions and expulsion for offenders. There is a willingness to make a Smoking Cessation Business program for smokers. Some bureaucratic structures already exist, but related to operational guidelines and technical guidelines as well as SOPs and division of tasks are still made improperly so it is necessary to conduct an evaluation by the health office of puskesmas that have not made SOP at all.
\end{abstract}

Keywords: Policy Implementation, No Smoking Areas (KTR), Health Facilities.

\begin{abstract}
ABSTRAK
Berbagai upaya menekan laju angka perokok aktif di Kabupaten Bungo dan melarang setiap aktivitas merokok diberbagai tempat dan fasilitas umum tertentu adalah menerbitkan perda KTR. Penelitian ini bertujuan untuk mengetahui dan menganalisis implementasi perda KTR pada fasilitas kesehatan yaitu puskesmas dalam Kabupaten Bungo. Penelitian ini menggunakan pendekatan metode kualitatif dengan data deskriptif. Untuk melihat keberhasilan implementasi kebijakan KTR pada puskesmas dalam Kabupaten Bungo digunakan pendekatan teori George Edwards III. Untuk analisis data digunakan model interaktif dari Miles dan Huberman. Kebasahan data digunakan pendekatan triangulasi sumber. Hasil penelitian menunjukkan bahwa pola komunikasi penerapan perda KTR di puskesmas dalam Kabupaten Bungo dilakukan dengan sosialisasi melalui rapat dipimpin oleh dinas kesehatan bersama seluruh kepala puskesmas. Selanjutnya pesan diteruskan kepada seluruh masyarakat oleh pihak puskesmas dengan via komunikasi secara verbabl dan non-verbal. Karena
\end{abstract}


pelaksana kebijakan tidak mendapatkan informasi secara langsung maka penerapan perda KTR ideal sebagaimana terdapat pada buku pedoman kemenkes dan tujuan perda KTR. Untuk sumber daya manusia pelaksana kebijakan terdiri atas unsur pimpinan dan pegawai yang ditunjuk oleh pihak puskesmas. Anggaran dana masih sedikit dalam pembuatan sarana penunjang KTR seperti spanduk, stiker serta tidak adanya insentif bagi pegawai pelaksana kebijakan. Disposisi penuh dari pihak puskemas serta masyarakat dengan memberikan sanksi lisan dan pengusiran bagi pelanggar. Adanya kemauan para dengan membuat program Usaha Berhenti Merokok kepada para perokok. Struktur Birokrasi dibeberapa sudah ada namun terkait dengan juklak dan juknis serta SOP dan pembagian tugas masih dibuat seadanya sehingga perlu dilakukan evaluasi oleh pihak dinas kesehatan terhadap puskesmas yang belum membuat SOP sama sekali.

Kata Kunci: Implementasi Kebijakan, Kawasan Tanpa Rokok (KTR), Fasilitas Kesehatan.

\section{PENDAHULUAN}

Undang-undang Nomor 39 Tahun 2009 Tentang Kesehatan menyatakan bahwa hak atas kesehatan terkait dengan upaya meminimalisasi dampak lingkungan bagi kehidupan manusia. Hal ini menegaskan bahwa kebutuhan akan hidup sehat merupakan jaminan dari negara kepada masyarakatnya. Namun kenyataan di berbagai daerah menunjukkan keterbalikan dari penegakan masyarakat yang sehat dan lingkungan bersih. Salah satu penyebab yang masih menjadi lawan negara adalah perilaku merokok yang semakin hari berdampak buruk bagi lingkungan dan manusia.

Aktivitas merokok merupakan suatu perilaku yang tidak sehat, selain berbahaya bagi diri sendiri terlebih lagi pada orang lain yang memiliki hak untuk menghirup udara yang bersih dan terhindar dari segala bahan cemaran yang dikeluarkan oleh asap rokok orang lain. Merokok telah memberikan implikasi besar terhadap lingkungan yang tidak sehat dan merokok dapat pula memberikan dampak yang lebih besar terhadap status kesehatan seseorang dan masyarakat secara keseluruhan.

Masalah merokok sampai saat ini masih menjadi masalah nasional yang secara terus-menerus diupayakan penanggulangan, karena menyangkut berbagai aspek permasalahan dalam kehidupan, yaitu aspek ekonomi, sosial, politik, utamanya aspek kesehatan. Oleh karena itu pemerintah mengupayakan penanggulangan bahaya rokok melalui pembatasan ruang gerak para perokok diberbagai tempat dan fasilitas umum. Selanjutnya pemerintah memberikan kewenangan kepada pemerintah daerah untuk melakukan pembatasan kepada para perokok melalui kebijakan pemerintah daerah masing-masing. Sebagaimana tertuang dalam Undang-undang Nomor 39 Tahun 2009 Tentang Kesehatan Pasal 115 ayat (1) dan Pasal 115 ayat (2): Pemerintah Daerah wajib menetapkan dan menerapkan Kawasan Tanpa Rokok (KTR) di wilayahnya.

Amanat undang-undang mengenai penetapan Kawasan Tanpa Rokok (KTR) ini disambut baik oleh berbagai daerah di Indonesia, salah satunya adalah Kabupaten Bungo, Provinsi Jambi dengan menyusun Peraturan Daerah Kabupaten Bungo Nomor 3 Tahun 2016 tentang Kawasan Tanpa Rokok (KTR) yang telah ditetapkan dan diundangkan pada tanggal 2 September 2016.

Mekanisme pelaksanaan perda KTR ini adalah melarang setiap orang atau badan yang menggunakan fasilitas umum dan tempat kerja menjadi tempat merokok. Khusus tempat kerja sebagaimana disebutkan pada perda ini, diwajibkan menyediakan tempat khusus bagi perokok yang secara teknis harus sesuai dengan peraturan. Selanjutnya mekanisme pelaksanaan perda KTR di Kabupaten Bungo khusus kepada orang atau badan yang menyelenggarakan reklame rokok dan tembakau tidak diperbolehkan 
meletakan reklame atau papan promosi pada kawasan KTR dan jalan utama atau protokol sebagaimana ketentuan dan mekanisme yang ada pada perda.

Perda KTR di Kabupaten Bungo memberikan kesempatan terkait pengawasan baik terhadap kegiatan yang boleh dan tidak diperkenankan oleh perda. Kesempatan tersebut adalah pengawasan terhadap pelaksanaan perda ini lebih kepada pengawasan bersifat sosial yang membutuhkan peran serta masyarakat dalam mewujudkan KTR. Seperti memberitahu, memperingatkan, mengusulkan dan melaporkan terkait pelanggaran yang dilakukan oleh perokok dan penyelenggara reklame rokok di tempat yang telah disebutkan.

Sebagaimana disebutkan di dalam perda KTR Kabupaten Bungo, bahwa setiap orang atau badan dilarang mempromosikan, mengiklankan, menjual dan membeli rokok di lokasi-lokasi KTR. Salah satu tempat yang termasuk Kawasan Tanpa Rokok untuk kegiatan promosi rokok terdapat di beberapa jalan, seperti: jalan utama Sri Soedewi, Sultan Thaha, Teuku Umar dan R.M Thaher. Namun berdasarkan hasil observasi yang dilakukan oleh peneliti, masih ditemukan papan reklame yang mempromosikan iklan rokok jenis tertentu pada bahu jalan sebagaimana yang ditetapkan dalam perda KTR. Selanjutnya penegakan dan pelarangan aktifitas merokok tidak berjalan sebagaimana aturan di dalam perda, hal ini masih terjadi banyaknya aktifitas merokok yang terjadi pada beberapa fasilitas umum seperti wilayah perkantoran, faskes dan di depan halaman sekolah-sekolah yang ada di Kabupaten Bungo.

Dalam rangka pelarangan aktivitas merokok di fasilitas kesehatan seperti puskemas yang ada di wilayah kabupaten Bungo juga tidak berjalan sebagaimana amanat dari perda. Masih terdapat pihak puskesmas yang tidak menjalankan berbagai kegiatan yang telah diamanatkan perda seperti tidak adanya kegiatan sosialisasi berkeseinambungan kepada masyarakat, masih sedikitnya pemasangan stiker di dalam ruangan dan pemasangan spanduk, serta tidak adanya pembagian tugas kepada pegawai terhadap mekanisme teknis pelaksanaan perda. Sisi lain masih ditemukan beberapa masyarakat yang mengunjungi puskesmas dalam keadaan merokok karena tidak ada pegawai yang tegas terhadap pelanggar. Kegiatan merokok pada lingkungan puskesmas kerap terjadi, seperti: seorang laki-laki yang mengantarkan istri, anak dan orang tuanya dan menunggu di luar puskesmas dengan melakukan aktivitas merokok. Selanjutnya tidak ada tindak lanjut dari pelarangan terhadap orang yang melakukan aktivitas merokok pada lingkungan puskesmas tersebut oleh pihak puskesmas.

Berdasarkan hasil observasi yang dilakukan, peneliti tertarik untuk mengkaji lebih komprehensif dan mendalam mengenai fenomena-fenomena yang terjadi dalam pelaksanaan perda KTR di puskesmas yang ada di Kabupaten Bungo. Penelitian ini bertujuan untuk mendeskripsikan dan menganalisis proses implementasi kebijakan kawasan tanpa rokok di Kabupaten Bungo serta mendeskripsikan faktor-faktor pendukung dan penghambat dalam proses implementasi kawasan tanpa rokok di Kabupaten Bungo.

\section{METODE PENELITIAN}

Pendekatan dalam penelitian ini menggunakan pendekatan kualitatif dengan analisis secara deskriptif. Informan ditentukan berdasarkan teknik purposive sampling dan random sampling yang terdiri dari informan instansi puskesmas dalam kabupaten bungo dan masyarakat yang datang mengunjungi puskesmas. Teknik pengumpulan data dilakukan dengan metode observasi, wawancara mendalam dan studi kepustakaan. Selanjutnya data yang telah dikumpulkan dianalisis interaktif menggunakan teknik analisa data dari miles dan huberman yang terdiri dari: mengumpulkan data, mereduksi, 
menyediakan dan menyimpulkan data. Untuk keabsahan data, peneliti menggunakan teknik triangulasi sumber.

\section{HASIL DAN PEMBAHASAN}

Hasil penelitian ini akan dibagi menjadi dua bagian, bagian pertama akan memaparkan hasil dari pelaksanaan perda KTR yang berdasarkan Perda Kabupaten Bungo No 3/2016 tentang KTR pasal 4 ayat 1 menyebutkan Kawasan Tanpa Rokok meliputi: (a) Fasilitas pelayanan kesehatan; (b) Tempat proses belajar mengajar; (c) Tempat anak bermain; (d) Tempat ibadah; (e) Angkutan umum; (f) Fasilitas olah raga; (g) Tempat kerja, dan (h) Tempat umum dan tempat lain yang ditetapkan dengan keputusan Bupati. Penelitian ini akan dikhususkan pada bagaimana pelaksanaan perda di beberapa puskesmas yang ada di Kabupaten Bungo. Pada bagian kedua peneliti akan menganalisis dan memaparkan hasil penelitian dengan menyadingkan dengan teori teori Edward III, yakni: (komunikasi, disposisi, sumberdaya dan struktur birokrasi)

Implementasi Kebijakan KTR pada fasilitas pelayanan kesehatan yang meliputi (RSUD H. Hanafie Kabupaten, Puskesmas Kecamatan Rimbo Tengah, Puskesmas Kec. Bathin III, Puskesmas Pembantu Sungai Kerjan).

Pada bagian ini dipaparkan mengenai pelaksanaan perda KTR di beberapa tempat pelayanan kesehatan sejak diberlakukan perda KTR. Hasil penelitian menunjukkan bahwa pelaksanaan perda KTR di RSUD H. Hanafie Kabupaten Bungo telah membuat batasan secara tegas terhadap aktifitas para perokok yang menunggu pasien. Pihak RSUD telah menyediakan tempat khusus bagi para perokok dengan diberikan pagar kawat yang tinggi dan berjarak sekitar 50 meter dari ruangan kamar pasien yang terletak di teras halaman. Namun di lokasi yang berbeda tidak disediakan tempat bagi perokok yang berada di sekitar halaman IGD serta poliklinik, pihak RSUD hanya meletakan papan peringatan saja bagi para perokok. Hal ini menyebabkan para perokok masih menyelinap dengan bebas untuk merokok.

Selanjutnya hasil penelitian pada Puskesmas Kecamatan Rimbo Tengah sudah melaksanakan perda KTR dengan memberikan teguran dan peringatan oleh kepada para pengunjung dan mengusir jika para pengunjung mengulang perbuatan merokok. Pihak puskesmas juga telah membuat program yang dinamakan UBM (Usaha Berhenti Merokok). Dimana seorang pengunjung akan diberikan waktu untuk konsultasi dilanjutkan dengan pemerikasaan terlebih dahulu di meja pendaftaran di berikan beberapa pertanyaan terkait status merokok atau tidak. Jika benar merupakan seorang perokok maka pasien tersebut akan dibina dan masuk ke dalam ruang UBM. Program ini diterapkan untuk mengurangi para perokok aktif dan perokok pemula. Para perokok diberikan waktu dua kali dalam seminggu untuk konsul selama enam bulan.

Selanjutnya hasil penelitian pada Puskemas Pembantu di Kelurahan Sungai Arang sudah menerapkan sejak ditetapkannya Perda KTR. Pihak puskesmas juga telah melakukan sosialisasi dan memberitahukan kepada para pengunjung dan masyarakat atau pasien yang hendak berobat ke puskesmas, bahkan petugas langsung mendatangi rumah-rumah masyarakat untuk mensosialisasikan perda KTR tersebut. Untuk para pengunjung yang melanggar dan terbukti merokok di lingkungan puskesmas, pihak puskesmas hanya memberi teguran saja dan menjelaskan bahwa Puskesmas ini adalah Kawasan Tanpa Rokok dan menyarankan untuk memilih tempat lain apabila ingin merokok. Untuk para pengunjung yang terbukti melanggar perda ini pada lingkungan puskesmas tidak diberikan sanksi pidana atau denda. 
Adapun pelaksanaan perda KTR di Puskesmas Kecamatan Battin III diantaranya melakukan penindakan pada lingkungan internal, terutama pemberian larangan keras kepada petugas untuk tidak boleh merokok di lingkungan puskesmas, setelah lalu diterapkan pada pasien atau pengunjung, jika ada yang merokok di dalam ruangan atau di wilayah puskesmas petugas mengingatkan bahwa puskesmas ini kawasan bebas rokok dan memberhentikan kegiatan merokok tersebut dengan menyuruh mematikan dan membuang puntung rokok tersebut jika masih ingin merokok petugas menyarakan untuk merokok diluar area atau pekarangan puskesmas. Petugas puskesmas Kecamtan Batin III juga telah melakukan sosialisasi ke beberapa sekolah dasar dan PAUD. Selanjutnya petugas puskesmas Kecamatan Battin III akan melakukan sosialisasi ke SMP dan SMA untuk menekakan angka bagi perokok pemula.

Penelitian implementasi kebijakan Kawasan Tanpa Rokok pada beberapa faskes di Kabupaten Bungo menggunakan pendekatan teori dari George Edward III dengan memperhatikan dan menganalisis empat variabel utama yaitu: komunikasi, sumber daya, disposisi dan struktur birokrasi. Penggunaan teori Edward ini disesuaikan dengan karakteristik penelitian dan permasalahan yang ada. Dari hasil penelitian yang telah dilaksanakan akan dibahas keempat faktor tersebut terkait pengimplementasian kebijakan KTR pada beberapa faskes di Kabupaten Bungo.

\section{Komunikasi}

Komunikasi adalah suatu kegiatan manusia untuk menyampaikan apa yang menjadi pemikiran dan perasaannya, harapan atau pengalamannya kepada orang lain. Menurut Edwards, persyaratan pertama bagi implementasi kebijakan yang efektif adalah bahwa mereka yang melaksanakan keputusan harus mengetahui apa yang harus mereka lakukan. Keputusan-keputusan kebijakan dan perintah-perintah harus diteruskan kepada personil yang tepat sebelum keputusan-keputusan dan perintah-perintah itu dapat diikuti.

Tentu saja, komunikasi-komunikasi harus akurat dan harus dimengerti dengan cermat oleh para pelaksana. Apa yang menjadi tujuan dan sasaran kebijakan harus disampaikan kepada kelompok sasaran (target) sehingga akan mengurangi dampak dari implementasi tersebut. Ketidakjelasan pesan komunikasi yang disampaikan berkenaan dengan implementasi kebijakan dan akan mendorong terjadinya interpretasi yang salah bahkan mungkin bertentangan dengan makna pesan awal. Jika implementasi kebijakan ingin berlangsung efektif, maka perintah-perintah pelaksanaan harus konsisten dan jelas (Winarno, 2015).

Berdasarkan hasil penelitian, dapat diketahui bahwa pola komunikasi sosialisasi Perda Kabupaten Bungo Nomor 3 Tahun 2016 tentang Kawasan Tanpa Rokok dari Pemerintah Daerah ke pihak pelayanan fasilitas kesehatan diperoleh dari dinas kesehatan Kabupaten Bungo, selanjutnya pihak dinas kesehatan Kabupaten Bungo menginformasikan ke beberapa puskesmas dalam lingkungan Kabupaten Bungo secara acak melalui pertemuan yang diadakan di kantor dinas kesehatan dengan mengundang setiap kepala puskesmas dan beberapa staf puskesmas. Informasi mengenai perda KTR ini tidak disampaikan secara langsung oleh Bidang sosial hukum setda Kabupaten Bungo yang membawahi semua peraturan daerah. Setda hanya berkoordinasi langsung melalui pihak dinas kesehatan Kabupaten Bungo.

Mengenai pemahaman para narasumber di beberapa puskesmas mengenai Kawasan Tanpa Rokok (KTR) juga dapat dilihat, telah dimengerti oleh informan namun hanya beberapa dari tempat-tempat kawasan tanpa 
rokok yang ditetapkan dalam perda yang dapat disebutkan oleh informan. Pada beberapa puskesmas seperti puskesmas di Kecamatan Bathin III tidak mendapatkan sosialisasi secara langsung dari setda bagian hukum pemerintah Kabupaten Bungo.

Sosialisasi mengenai sebuah aturan merupakan hal terpenting dalam memberikan pemahaman untuk mengimplementasikan sebuah kebijakan karena sosialisasi merupakan tahap awal pendistribusian informasi terkait isi kebijakan, manfaat kebijakan, tujuan kebijakan sasaran dan ruang lingkup kebijakan Kawasan Tanpa Rokok. Sosialisasi dan distribusi informasi mengenai isi dan tujuan kebijakan dapat dilakukan oleh pemerintah melalaui beberapa cara, yakni sosialisasi secara virtual dengan memanfaatkan media elektronik; televisi, radio, media sosial dan pesan berantai serta bisa menggunakan media; koran, papan pengumuman, spanduk dan pamflet.

\section{Sumber Daya}

Sumber daya dalam implementasi kebijakan merupakan aspek penting dan mendominasi guna mencapai tujuan kebijakan. Tetapi jika para pelaksana kekurangan sumber-sumber yang diperlukan untuk melaksanakan kebijakankebijakan, maka implementasi ini pun cenderung tidak efektif dan tidak bisa mencapai tujuan kebijakan. Sumber daya yang utama dalam melaksanakan kebijakan adalah staf pelaksana atau disebut juga dengan implementor kebijakan. Para implementor kebijakan harus berjumlah cukup dan sesuai dengan kebutuhan dalam melaksanakan kebijakan dengan memiliki kemampuan dan pemahaman yang komprehensif terhadap kebijakan yang akan dilaksanakan.

Sebaik apapun konsep dan tujuan terhadap suatu kebijakan serta kemauan atau sikap untuk menjalankannya dengan serius, akan tetapi tidak didukung oleh sumberdaya yang baik, maka implementasi dari sebuah kebijakan akan tidak berjalan maksimal. Sumber daya mempunyai pengaruh yang sangat besar dalam menyukseskan suatu implementasi kebijakan. Sebab dengan ketersediaan sumber daya yang cukup, akan memudahkan tujuan dari suatu kebijakan tercapai. Sumber daya yang dimaksud adalah mulai dari sumber daya manusia maupun sumber daya non-manusia.

Berdasarkan hasil penelitian di lapangan, dapat diketahui bahwa yang menjadi sasaran pelaksanan kebijakan kawasan tanpa rokok yaitu Sumber Daya Manusia (SDM) yang ada di beberapa puskesmas dalam Kabupaten Bungo mulai dari kepala puskesmas, pegawai sampai kepada masyarakat yang mengunjungi puskesmas. Fakta di lapangan menunjukkan bahwa sumberdaya manusia di beberapa puskesmas sudah memiliki dokumen dan SOP terkait implementasi kebijakan KTR. Namun di beberapa puskesmas juga ada yang belum memiliki pedoman teknis pelaksanaan KTR.

Terkait sarana dan prasarana atau infrastruktur kawasan tanpa rokok di beberapa puskesmas dalam Kabupaten Bungo yaitu ketersediaan spanduk di halaman dan gerbang pintu masuk puskesmas, di dalam ruang tunggu dan beberapa stiker di dinding ruang inap dalam puskesmas. Pada pelaksanaan Kawasan Tanpa Rokok, anggaran dana menjadi faktor yang penting juga namun dari hasil penelitian tidak ada pengalokasian anggaran dana khusus dari pemerintah maupun dari puskesmas.

Menurut Pedoman Pengembangan KTR Kemenkes (2011). Pelaksana kebijakan KTR harus memiliki pedoman yang berisikan informasi dan tata cara bagaimana menerapkan KTR. Aktor pelaksana kebijakan pada level 
puskesmas sedianya harus memenuhi beberapa hal agar dapat menerapkan KTR dengan efektif. Antara lain, infrastruktur sarana dan prasarana yang memadai untuk pelaksanaan Kawasan Tanpa Rokok (KTR) seperti, tulisan, poster dan spanduk larangan merokok.

\section{Disposisi}

Disposisi atau sikap dari pelaksana kebijakan adalah faktor penting dalam pendekatan mengenai pelaksanaan suatu kebijakan publik. Jika pelaksanaan kebijakan ingin efektif, maka para pelaksana kebijakan tidak hanya harus mengetahui apa yang akan dilakukan namun juga harus memiliki kemampuan untuk melaksanakan sehingga dalam prakteknya tidak bias. Menurut Edwards (dalam Nugroho, 2014: 166) mendefinisikan disposisi sebagai kumpulan sikap-sikap pilihan dengan kemampuan yang memungkinkan sikap-sikap pilihan tadi muncul dengan cara tertentu

Dalam implementasi kebijakan menurut George C. Edward III, jika ingin berhasil secara efektif dan efisien, para implementor harus memiliki kemauan dan rasa sukarela untuk mengimplementasikan kebijakan. Kebijakan yang efektif dapat terjadi apabila mendapat dukungan penuh dari implementor. Selanjutnya implementor harus memiliki visi dan tujuan yang sama sesuai dengan tujuan kebijakan yang telah ditetapkan dengan menyatukan pandangan dan sikap kepedulian tanpa adanya unsur kepentingan pribadi atau kelompok.

Implementor yang dimaksud pada proses implementasi kebijakan KTR ini adalah mulai dari pucuk pimpinan tertinggi seperti; kepala dinas kesehatan, kepala bidang, kepada puskesmas dan unsur masyarakat dan seluruh orang yang tergabung dan memiliki kepentingan dalam pelaksanaan kebijakan KTR.

Hasil penelitian menunjukkan bahwa penerapan kebijakan Kawasan Tanpa Rokok di beberapa puskesmas dalam Kabupaten Bungo terlihat mendapat dukungan baik dari internal maupun eksternal. Dukungan dari internal pihak puskesmas misalnya terjadi mulai dari kepala puskesmas dan pegawainya mematuhi aturan KTR dengan tidak merokok di beberapa tempat yang dilarang oleh pihak puskesmas. Pemberian teguran dan sanksi diterapkan oleh pihak pegawai puskesmas bagi pelanggar dari pegawai atau staf dan masyarakat yang berkunjung ke puskesmas dengan tidak memperbolehkan masuk ke lingkungan puskesmas.

\section{Struktur Birokrasi}

Menurut Edwards (dalam Nugroho, 2014: 168-169) pelaksanaan kebijakan bisa jadi masih belum efektif karena ketidakefisienan struktur birokrasi. Struktur birokasi ini menurut Edward mencakup aspek-aspek seperti struktur birokrasi, pembagian kewenangan, hubungan antara unit-unit organnisasi dan sebagainya. Terdapat dua karakteristik utama dari birokrasi yakni: Standard Operational Procedure (SOP) dan fragmentasi.

Standard Operating Procedures (SOP) adalah suatu kegiatan rutin yang memungkinkan para pegawai atau pelaksana kebijakan untuk melaksanakan berbagai kegiatannya setiap hari sesuai dengan standar yang telah ditetapkan. Dengan menggunakan SOP, para pelaksana kebijakan dapat memanfaatkan waktu yang tersedia. Fragmentasi adalah upaya penyebaran tanggung jawab kegiatan-kegiatan dan aktivitas-aktivitas pegawai di antara beberapa unit.

Hasil penelitian dan pernyataan dari beberapa nara sumber di beberapa puskesmas dalam Kabupaten Bungo menunjukkan bahwa sebagian besar pihak puskesmas belum punya struktur birokrasi khusus dalam penerapan Kawasan Tanpa Rokok di puskesmas begitu juga dengan tidak adanya SOP khusus 
penerapan KTR. Menurut Pedoman Pengembangan KTR Kemenkes (2011), sekolah seharusnya memenuhi beberapa hal agar dapat menerapkan KTR dengan efektif, yaitu membentuk komite atau kelompok kerja penyusunan kebijakan KTR di puskesmas, dalam komite atau kelompok kerja tersebut akan dibentuk pengawas KTR yang secara langsung mengawasi penerapan KTR di sekolah. Berdasarkan kegiatan pengawasan KTR tersebut maka dapat dilakukan kegiatan pemantauan dan evaluasi penerapan KTR.

Sedangkan fragmentasi adalah suatu pembagian tugas atau tanggung jawab kepada anggota di beberapa posisi yang telah ditetapkan. Hal ini berdasarkan hasil penelitian tidak ada dibentuk kelompok kerja pelaksanaan kebijakan kawasan tanpa rokok di lingkungan puskesmas. Tidak ada pembagian wewenang khusus yang dibentuk. Proses pengawasan Kawasan Tanpa Rokok juga tidak ada ditentukan secara khusus. Tidak terdapat struktur birokrasi yang khusus dan SOP yang harusnya digunakan belum ada.

\section{IV.KESIMPULAN}

Berdasarkan hasil penelitian mengenai implementasi kebijakan perda Nomor 3 Tahun 2016 tentang Kawasan Tanpa Rokok pada beberapa puskesmas di Kabupaten Bungo dapat disimpulkan:

a. Pada variabel komunikasi penerapan perda KTR di beberapa puskesmas dalam Kabupaten Bungo dilakukan dengan kegiatan sosialisasi yakni melalui rapat dipimpin oleh dinas kesehatan Kabupaten Bungo menginformasikan ke seluruh kepala puskesmas. Selanjutnya pihak puskesmas meneruskan pesan kepada seluruh masyarakat mengenai perda KTR. Komunikasi yang dilakukan pihak puskesmas kepada masyarakat dilakukan dengan cara verbal yaitu menyampaikan sedikit banyak substansi kebijakan mengenai KTR secara langsung kepada masyarakat pada kegiatan-kegiatan tertentu. Komunikasi non verbal dilakukan melalui pesan-pesan memanfaatkan media elektronik dan cetak. Terkait dengan sosialisasi penerapan Kawasan Tanpa Rokok dari pemerintah langsung belum ada, sehingga pelaksana kebijakan kurang memahami bagaimana penerapan yang ideal untuk mencapai tujuan perda kawasan tanpa rokok oleh pihak puskesmas.

b. Sumber daya yang dimiliki yaitu sumber daya manusia yang teridiri atas semua unsur pimpinan dan pegawai puskesmas hingga para pengunjung dan masyarakat sebagai pelaksana pengawasan penerapan perda KTR. Untuk sumber anggaran dana masih sedikit, terutama untuk pembuatan sarana sebagai media penunjang KTR seperti spanduk, stiker yang belum sepenuhnya terpasang pada setiap sudut atau bagian-bagian ruangan di dalam dan luar puskesmas.

c. Disposisi para implementor dan stakeholder pelaksana kebijakan KTR yaitu adanya dukungan dan dari semua pihak puskemas serta masyarakat untuk taat pada aturan KTR dengan memberikan sanksi berupa teguran lisan dan pengusiran bagi pelanggar yang kedapatan merokok pada area puskesmas. Kemauan dan keinginan para pelaksana kebijakan dengan membuat program Usaha Berhenti Merokok kepada para peroko agar menurunkan angka perokok. Namun masih ada yang melanggar aturan merokok di dalam area puskesmas sehingga dilakukan pengusiran dan menyuruh mematikan rokok pada area puskesmas.

d. Struktur Birokrasi penerapan perda KTR di beberapa puskesmas dalam Kabupaten Bungo sudah ada yakni terkait dengan pembuatan juklak juknis oleh pihak puskesmas didukung dengan adanya aturan tersendiri di puskesmas, namun belum semua puskesmas memiliki SOP dan pembagian wewenang yang jelas terkait 
penerapan perda KTR sehingga masih perlu dilakukan evaluasi oleh pihak dinas kesehatan terhadap puskesmas yang belum membuat SOP tersebut.

\section{UCAPAN TERIMA KASIH}

Puji syukur penulis ucapkan kehadirat Allah SWT atas segala limpahan nikmat dan karunia yang tak terhingga, sehingga penulis dapat menyelesaikan artikel yang berjudul "Studi Implementasi Kebijakan Kawasan Tanpa Rokok Pada Fasilitas Pelayanan Kesehatan di Kabupaten Bungo." Penulisan artikel ini tentunya tidak akan selesai dengan baik tanpa bantuan dari pihak-pihak yang dengan tulus baik secara langsung maupun tidak langsung membantu penulis dalam penulisan artikel ini. Penulis mengucapkan terima kasih tak terhingga kepada pihak kampus STIA Setih Setio, civitas akademika kampus STIA Setih Setio, pihak puskesmas yang telah bersedia meluangkan waktu untuk memberikan informasi dan semua pihak yang telah memberikan dukungan dan bantuan baik secara moril dan materil. Semoga artikel ini dapat bermanfaat bagi civitas akademik dan juga perkembangan ilmu pengetahuan khususnya bidang ilmu administrasi negara.

\section{DAFTAR PUSTAKA}

Agustino, Leo. 2012. Dasar-Dasar Kebijakan Publik. CV. Alfabeta: Bandung.

Hendry Eka Prasetya , Ari Subowo, Aufarul Marom. 2015. Implementasi Kebijakan Kawasan Tanpa Rokok Di Stasiun Tawang Kota Semarang, Jurusan Administrasi Publik, Fakultas Ilmu Sosial dan Ilmu Politik, Universitas Diponegoro. Semarang.

Kementerian Kesehatan RI. 2011. Pedoman Pengembangan Kawasan Tanpa Rokok Jakarta: Kementerian Kesehatan RI.

Kurnia. S. 2019. Implementasi Kawasan Tanpa Rokok (Ktr) Pada Sekolah Menengah Atas (SMA) Di Kecamatan Mariso Kota Makassar. Skripsi. Makassar: Fakultas Kedokteran Dan Ilmu Kesehatan Uin Alauddin Makassar

Menteri Kesehatan, Menteri Dalam Negeri RI. 2011. Peraturan Bersama Menteri Kesehatan dan Menteri Dalam Negeri Nomor 7 Tahun 2011 tentang Pedoman Pelaksanaan Kawasan Tanpa Rokok.

Moleong, Lexy J. 2009. Metode Penelitian Kualitatif. Bandung: Remaja Rosdakarya.

Nizwardi Azkha. 2013. Studi Efektivitas Penerapan Kebijakan Perda Kota Tentang

Kawasan Tanpa Rokok (KTR) Dalam Upaya Menurunkan Perokok Aktif Di

Sumatera Barat Tahun 2013. Jurnal Kebijakan Kesehatan Indonesia. Vol. 02,

No. 04. Hal 171 - 179, Fakultas Kesehatan Masyarakat, Universitas Andalas. Padang.

Nugroho, Riant. 2014. Public Policy. PT Elex Media Komputindo. Jakarta.

Nugroho, Riant. 2003. Kebijakan Publik: Formulasi, Implementasi, dan Evaluasi, Jakarta : Elex Media Komputindo

Peraturan Daerah Kabupaten Bungo Nomor 3 Tahun 2016 tentang Kawasan Tanpa Rokok (KTR)

Peraturan Pemerintah RI. 1999. Peraturan Pemerintah Republik Indonesia Nomor 81 Tahun 1999 Tentang Pengamanan Rokok Bagi Kesehatan.

Peraturan Pemerintah RI. 2000. Peraturan Pemerintah Republik Indonesia Nomor 38 Tahun 2000 Tentang Perubahan Atas Peraturan Pemerintah Nomor 81 Tahun 1999 Tentang Pengamanan Rokok Bagi Kesehatan. 
Peraturan Pemerintah RI. 2003. Peraturan Pemerintah Republik Indonesia Nomor 19 Tahun 2003 tentang Pengamanan Rokok Bagi Kesehatan.

Peraturan Pemerintah RI. 2012. Peraturan Pemerintah Republik Indonesia Nomor 109

Tahun 2012 tentang Pengamanan Bahan yang Mengandung Zat Adiktif Berupa Produk Tembakau Bagi Kesehatan

Satori, Djam'an dan Komariah, Aan. Metodologi Penelitian Kualitatif. 2013. Bandung: Alfabeta

Sugiyono, 2008, Metode Penelitian Kualitatif dan Kuantitatif dan R\&D, Alfabeta, Bandung.

Undang-undang Nomor 39 Tahun 2009 Tentang Kesehatan

Wahab, Solichin, Abdul, 2015, Analisis Kebijakan: Dari Formulasi ke Penyusunan Model-model Implementasi Kabijakan Publik, Bumi Aksara, Jakarta.

Winarno, Budi, 2014, Kebijakan Publik (Teori, Proses dan Studi Kasus), CAPS, Yogyakarta.

Winarno, Budi. 2015. Kebijakan Publik: Teori, Proses, dan Studi Kasus. CAPS. Yogyakarta 